\title{
Morphometry of The Reproductive Organs of Female Bandicoots (Echymipera kalubu)
}

\author{
(MORFOMETRI ORGAN REPRODUKSI \\ BANDIKUT (ECHYMIPERA KALUBU) BETINA
}

\section{Fahry Rafli, Angelina Novita Tethool, Freddy Pattiselanno}

Animal Production Department, Faculty of Animal Science, University of Papua (Unipa) Kampus Unipa, Jalan Gunung Salju Amban Manokwari

Papua Barat, Indonesia, 98314

Email: angelinanovitatethool@gmail.com

\begin{abstract}
Information about bandicoots in Papua is very limited, because most of the studies conducted are focusing on ecology with study areas in other parts of Indonesia New Guinea. Our knowledge about the reproductive organs of bandicoots, especially females as a local genetic source, is almost completely nonexistent. Meanwhile, on the other hand, the development of captive breeding efforts for endemic Papuan animals including bandicoots is currently a concern. Therefore, research on the reproductive organs of female bandicoots is very urgent to get an idea of the reproductive organs that play an important role in the development of captive breeding program. This research was conducted at the Laboratory of Physiology and Animal Reproduction, Faculty of Animal Husbandry, University of Papua from 15 June to 15 September 2017. The reproductive organs of female bandicoots were obtained from female bandicoots hunted around Manokwari. Three female reproductive organs of the bandicoot (Echymipera kalubu) were used in this study, and the morphology of their reproductive organs was observed according to the purpose of the study. As a comparison the reproductive organs of D. minustus were used in this study. The results showed that the female reproductive organs of E. kalubu had an "advanced duplex" type with a pair of ovaries, fallopian tubes, uterus, vaginal cul de sac, cervix and lateral vagina. Morphologically, the reproductive organs of $E$. kalubu have a certain uniqueness, different from the reproductive organs of other female marsupials, so they need serious attention in developing captive breeding program in the near future.
\end{abstract}

Keywords: Morphometry, reproductive organs, female, Echymipera kalubu

\begin{abstract}
ABSTRAK
Informasi tentang bandikut di Papua sangat terbatas, karena sebagain besar kajian yang dilakukan adalah tentang ekologi dengan wilayah kajian di bagian lain pulau New Guinea - Indonesia New Guinea. Pengetahuan kita tentang organ reproduksi bandikut, khususnya betina sebagai sumber genetik lokal hampir sama sekali tidak ada. Sementara itu di sisi lain pengembangan usaha penangkaran satwa endemic Papua termasuk dandikut saat ini sedang menjadi perhatian. Oleh karena itu penelitian tentang organ reproduksi bandikut betina sangat urgen untuk mendapatkan gambaran tentang organ reproduksi yang berperan penting dalam pengembangan usaha penangkaran. Penelitian ini dilakukan di Laboratotirum Fisiologi dan Resproduksi Hewan, Fakultas Peternakan Universitas Papua antara tanggal 15 Juni sampai dengan 15 September 2017. Organ reproduksi bendikut betina diperoleh dari bandikut betina hasil buruan di sekitar Manokwari. Tiga organ reproduksi betina bandikut (Echymipera kalubu) digunakan dalam penelitian ini, dan morfologi organ reproduksinya telah diamati sesuai dengan tujuan penelitian. Sebagai pembanding dalam penelitian ini adalah organ reproduksi D. minustus. Hasil penelitian menunjukan bahwa organ reproduksi $E$. kalubu betina memiliki type "advanced duplex" dengan sepasang ovary, tuba fallopii, uterus, vagina cul de sac, serviks dan vagina lateral. Secara morfologi, organ reproduksi $E$. kalubu memiliki keunikan tertentu, berbeda dengan umumnya organ reproduksi marsupial betina lainnya, sehingga perlu perhatian serius dalam pengembangan usaha penangkaran di waktu mendatang
\end{abstract}

Kata-kata kunci: Morfometri, organ reproduksi, betina Echymipera kalubu. 


\section{INTRODUCTION}

Bandicoots have the highest reproductive rate among the marsupialias. Each year, female bandicoots can give birth 5-6 times with an average litter size 3-4, 12-13 days of pregnancy and 50-60 days of breastfeeding (Petocz, 1994). They have unique structure of reproductive organs, where the end of the reproductive tract, urinary and sewerage empties into the cloaca of the anal canal is similar in poultry (Warsono, 2009).

Bandicoots (Echymipera kalubu) is one among wildlife species that was highly utilized in Papua (Pattiselanno, 2003); with an average consumption of their meat by Warmare communities in Manokwari was $60 \mathrm{~kg} /$ capita/ hunting season (Murwanto et al., 2008). Its high reproduction ability would be a good opportunity for the development of bandicoots farming as a solution to reduce direct harvest rates form the nature for animal protein sources. However, the acknowledgement of the female bandicoots reproductive system as a local genetic source is very limited or completely absent.

Different studies on the reproduction of bandicoots have been widely explored for example: the production of Brown Bandicoot (Isodon (I) macrourus) (Vernes and Pope, 2009); the rhythm activities of Southern Brown Bandicoot (I. obelus) in captivity, reproductive physiology of female Bilby (Larcombe, 2003), reproductive physiology of female Bilby (Macrotislagotis thylacomidae) (Ballantyne et al., 2009); the influence of seasonal changes in the male bandicoot's (I. macrourus) reproductive tract (Thodunter and Gemmel, 1987) and the habits of digging as environmental adaptation (Long, 2009).

Information on bandicoots in Papua is inadequate, studies that have been conducted were more focusing on the daily behaviour of bandicoots in captivity, the biological and carcasses of bandicoots (Warsono, 2010; reproductive and sperm characteristics of male bandicoots (E. kalubu) (Tethool et al., 2012), and gastrointestinal morphology of bandicoots $(E$. kalubu) (Maker et al., 2015). Regrettably, the morphometry and physical description of reproductive organs of female bandicoots is less well understood. Thus, obtaining a better understanding of both physical shape and anatomy of the female reproductive organs will complete the description for both male and female bandicoots and provide very useful information to support the current program for bandicoots farming in Papua.

\section{RESEARCH METHODS}

Three female reproductive organs of bandicoots (E. kalubu) collected from hunters by using traditional traps, before they further processed. Hunters set foot-snare to catch bandicoots, thus all animals are caught alive. Specimens were obtained from Amban Pantai (North Manokwari District), Angkasa Mulyono (West Manokwari District) and SP9 (District of Prafi), described and measured at the Animal Physiology and Reproduction Laboratory, Faculty of Animal Science, Universitas Papua. The observation of reproductive tracts: ovary, tuba fallopian, cervix uterus, lateral vagina cul de sac, corpus uterus and vagina lateral (right and left), including the shape, color and texture were taken place, documented, measured (length, wide and diameter) and weighed (weight). The methods used exsanguination technique of the common carotid artery after anesthesia by using ketamine-xylazin $50 \mathrm{mg} / \mathrm{kg}$ and $10 \mathrm{mg} / \mathrm{kg}$ body weigth (Tethool et al., 2012). Length of reproduction organ, ovary, tuba falopian, uterine, cervix and vagina lateral measured by using microcaliper and tape (Koibur et al., 2001).

\section{RESULTS AND DISCUSSION}

The body weight of each individual is as follow 1) $511 \mathrm{~g}, 2) 335 \mathrm{~g}$, 3) $351 \mathrm{~g}$ with an average of $399 \pm 97,32 \mathrm{~g}$. The female reproductive organs of bandicoot (E. kalubu) consisted of pair of ovaries, fallopian tubes, uterus, cul de sac vaginas cervical and lateral vaginal located along the lower abdomen to the middle abdominal cavity (Figure 1).

Observation on morphometry and physical description of the reproductive organs showed the variation in size, color and texture of some observed variables (Table 1).

\section{Echymipera kalubu Ovary}

The E. kalubu's ovary's weight is $0.01 \pm$ $0.0048 \mathrm{~g}$ (right) and $0.02 \pm 0.0006 \mathrm{~g}$ (left). Individually, the left ovary of sample number two was bigger $(0.0193 \mathrm{~g})$ and the right ovary was smaller $(0.009 \mathrm{~g})$ than the other two samples (one and three). The ovary was located under the colon (large intestine) and the shape was like 

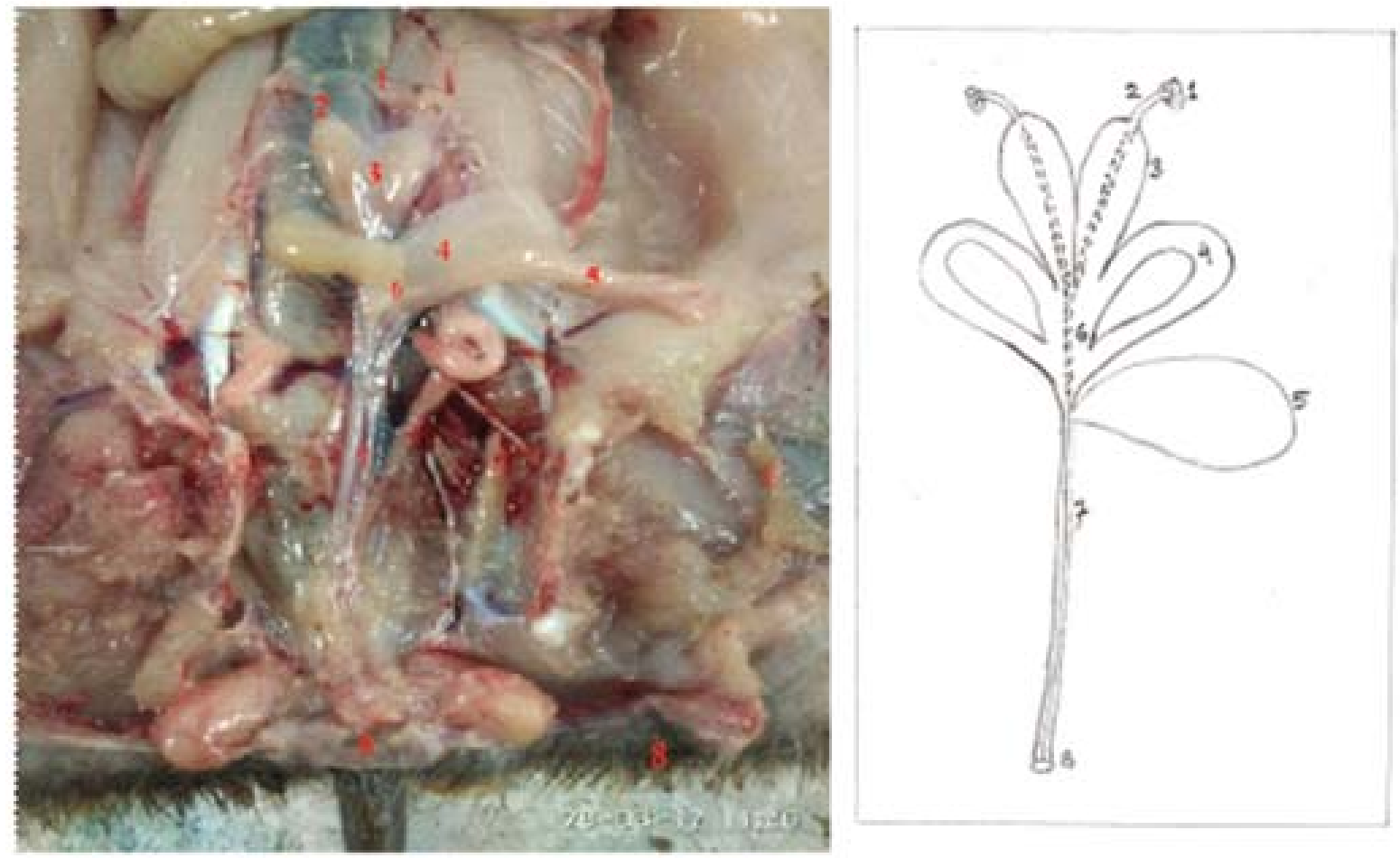

Figure 1. Reproductive organ of female Bandicoot (Echymipera kalubu): 1. ovary; 2. tuba falopii; 3. uterus; 4. vagina caecum; 5 . bladder; 6 . vagina cul de sac, cervix; 7 . vagina lateral; 8 . cloaca (urogenital sinus) from the field at the left side, and the sketch in the right side.

grape fruits. We compare our results with another marsupialia - Dendrolagus inustus with a larger body size, its ovary was oval in shape. The ovary weight was $0.59 \pm 0.09 \mathrm{~g}$ (left) and $0.65 \pm 0.17 \mathrm{~g}$ (right) (Koibur et al., 2011)

Individually, the left ovary of sample number two was bigger and the right ovary was smaller than other two samples (number one and number three). This condition was perhaps, caused by the development of follicles in the ovaries which has reached de Graaf phase on the left ovary development while the right part was suspected delayed. Large ovary certainly influenced the weight of ovary itself and was closely related to the amount of follicle de Graaf produced. The production of follicle de Graaf was biologically depending on heredity and environmental factors.

Differences in weight of the ovaries may also due to abnormalities occur to sample number two. Abnormality in an individual can occur partially or completely in particular organ (could be male or female individual). Those organs are genetically or environmentally more likely experiencing developmental abnormalities, so that the organs tend to be larger or smaller than the normal size. There is a tendency of one or all parts of the reproductive organs (male or female), the left sometimes (right is rarely) progressing imperfect (rudimentary) cause it looks very small or even non-existent, maybe because of environmental effects or heredity of the individuals (Hafez, 2000). The ovary size depended on the age of the animals and their reproductive cycles.

The shape of ovary in this study is similar to ovary of some mammals are identical to grape's shape. Red hearts of the ovaries may be due to hormonal influences and blood capillaries. As explained before, in the phase of de Graaf, follicles expanded because the influenced of FSH (Follicle Stimulating Hormone) and estradiol production, that developed and filled with follicular fluid. Estradiol increased blood supply to the genital tract and boosted follicle development in the ovary.

\section{Tuba fallopian of Echymipera kalubu}

The tuba fallopian of $E$. kalubu varies in length between 3.3 and $3.5 \mathrm{~cm}$ (right), average $3.43 \pm 0.12 \mathrm{~cm}$ and $3.0-3.6 \mathrm{~cm}$ (left), average 3.37 $\pm 0.32 \mathrm{~cm}$. The position of tuba fallopian near the lower abdomen between the ovary and the uterus, with spiral-shaped long channel (twisted) and pale white color. Physically, the texture of 
Tabel 1. Morphopmetry and physical description (location, shape, color and texture) of reproductive organ of female bandicoot (Echymipera kalubu)

\begin{tabular}{|c|c|c|}
\hline Component & Average & Physical Description \\
\hline $\begin{array}{l}\text { Length of Right Reproduction } \\
\text { Organ }(\mathrm{cm})\end{array}$ & $11.00 \pm 0.87$ & - \\
\hline $\begin{array}{l}\text { Length of Left Reproduction } \\
\text { Organ }(\mathrm{cm}) \\
\text { Ovary weight }(\mathrm{g})\end{array}$ & $11.03 \pm 0.84$ & \\
\hline Right & $0.01 \pm 0.0048$ & - Position: under the colon tract \\
\hline Left & $0.02 \pm 0.0006$ & $\begin{array}{l}\text { - Like grape shape } \\
\text { - Read heart in color } \\
\text { - Texture: Chewy serrated }\end{array}$ \\
\hline Length of Tuba fallopii (cm) & & \\
\hline Right side & $3.43 \pm 0.12$ & - Location: between over and utery \\
\hline Left side & $3.37 \pm 0.32$ & $\begin{array}{l}\text { - Form: spiral } \\
\text { - Pale white in color } \\
\text { - Texture: chewy soft }\end{array}$ \\
\hline \multicolumn{3}{|c|}{ Length and diameter of Utery $(\mathrm{cm})$} \\
\hline Right side & $1.73 \pm 0.25$ & $\begin{array}{l}\text { - Position: betweenn tuba falopii and vagina } \\
\text { cul de sac }\end{array}$ \\
\hline Left side & $1.83 \pm 0.29$ & - Form: Round at top and taper at the bottom \\
\hline Right side & $0.47 \pm 0.06$ & - Red mixed with white pale in color \\
\hline $\begin{array}{l}\text { Left side } \\
\text { Length of Cervix }(\mathrm{cm})\end{array}$ & $0.47 \pm 0.06$ & - Texture: thin, soft and chewy \\
\hline Right side & $0.50 \pm 0.00$ & - Position: between utery and vagina lateral \\
\hline Left side & $0.50 \pm 0.00$ & $\begin{array}{l}\text { - Shape: extended channel } \\
\text { - Red mixed with white pale in color } \\
\text { - Texture: hard, thick, dense and chewy }\end{array}$ \\
\hline \multicolumn{3}{|l|}{ Length of Vagina Lateral $(\mathrm{cm})$} \\
\hline Right side & $5.33 \pm 0.58$ & $\begin{array}{l}\text { - Location: at the back of the pelvic cavity } \\
\text { under the bladder near the cloaca }\end{array}$ \\
\hline Left side & $5.33 \pm 0.58$ & $\begin{array}{l}\text { - Long channel in shape } \\
\text { - Red mixed with white pale in color } \\
\text { - Chewy in texture }\end{array}$ \\
\hline
\end{tabular}

Note: $\mathrm{N}=3$; Average Body Weight $=399 \pm 97,32 \mathrm{~g}$; Average Body Length=21,67 $\pm 5,51 \mathrm{~cm}$.

tuba fallopian was soft and chewy. According to Koibur et al. (2011), tuba fallopian of Dendrolagus inustus was small and long round. The length of tuba fallopian was $3.00 \pm 0.00 \mathrm{~cm}$ (left) and $3.26 \pm 0.18 \mathrm{~cm}$ (right). The description of the fallopian tubes in this study was coil shaped and the consistence was flexible

\section{Uterine of Echymipera kalubu}

An average length of the right uterus of $E$. kalubu is $1.73 \pm 0.25 \mathrm{~cm}$ with an average diameter $0.47 \pm 0.06 \mathrm{~cm}$. The length of the left uterus is $1.83 \pm 0.29 \mathrm{~cm}$ in average with its diameter $0.47 \pm 0.06 \mathrm{~cm}$. Echymipera kalubu has an advanced duplex type of uterine, with a pair of the uterus. The uterine is located in the body cavity near the lower abdomen between the fallopian tubes and cervix, round-shaped with a pointy, mixed with pale red and has a thin texture, soft and supple. According to Koibur et al. (2011), D. inustus has a length uterine $4.00 \pm 0.00 \mathrm{~cm}$ (left) and $4.80 \pm 0.45 \mathrm{~cm}$ (right).

\section{Vagina Cul de sac of Echymipera kalubu}

Cervix is found in Vagina cul de sac at the anterior end portion of the lateral vagina. The right and left cervix of the E. kalubu is (similar $0.50 \pm 0.00 \mathrm{~cm}$ ) in length. The length of right and left of E. kalubu's cervix of all samples is not different. The cervix was channel-protrudes in shape, located between uterus and the lateral vagina and had a hard, thick, solid and fibrous texture. 
The vaginal area is the largest part of the female marsupial's reproductive tract, consists of two lateral vaginas, each of them connects to the uterus from the same side to the urogenital sinus (cloaca) Fletcher (1881; 1883), and Barbour (1977). The anterior end of each lateral vagina usually separated only by the media septum that configuring vagina cul de sac, where urterine cervix was exposed.

Vagina cul de sac is the anterior end portion of the lateral vagina, connecting it to the uterus and in this section uterine cervix is found (Tyndale-Biscoe, 1965; 1968). It presumed that cervix was found inside vagina cul de sac vagina with a thick texture, almost identical to the cervical features found in mammals. The cervical skeletal layer in mammals is very thick.

\section{Vagina Lateral of Echymipera kalubu}

The length of the right and left of E. kalubu's lateral vagina was similar, with an average (5.33 $\pm 0.58 \mathrm{~cm})$. There are two channels extending from the top of cloaca to the bottom of vagina cul de sac. The vagina is located at the back of the lower pelvic cavity of the urine bag near to cloaca.

Previous studies, Lister and Fletcher (1881) and Fletcher (1881; 1883), and Barbour (1977) indicated that the marsupial's vagina consisted of two lateral vaginas. The bhipid-shaped glands of the penis that described by previous studies may be associated with a two-part marsupial vaginal form: two lateral vaginas and median vagina (Biscoe and Renfree 1987). It was evidenced that the position of vagina of some was at the back of the pelvic cavity. According to Tyndale-Biscoe $(1965,1968)$; the shape of lateral vagina varies among some marsupials. In some species, the anterior part may expand to as a pitcher or semen container. During the process of copulation, it was formed as single central cubicle called vaginal caecum (Peremelidae, Potoroinae); otherwise it was enlarged (Macropodinae).

\section{CONCLUSION}

Morphologically, the shape and model of the reproductive organs of $E$. kalubu are different with the common marsupial female organs. As we compare the reproductive organs of E. kalubu with $D$. inustus, it seems that it has an advanced duplex type with a pair of ovaries, fallopian tubes, uterus, cul de sac vaginas, cervixes and lateral vaginas. The average length of the right and left reproductive organs was $11.05 \pm 0.85 \mathrm{~cm}$. The mean weight of the right and left ovaries was $0.015 \pm 0.00 \mathrm{~cm}$, and the mean length of the right and left fallopian tubes was $3.4 \pm 0.02 \mathrm{~cm}$. The mean length of right and left uterus was $1.78 \pm 0.27 \mathrm{~cm}$ in length, with the mean of diameter was $0.47 \pm 0.06 \mathrm{~cm}$. Both mean length of the right and left cervixes and lateral vaginas was $0.50 \pm 0.00 \mathrm{~cm}$ and $5.33 \pm 0.58 \mathrm{~cm}$.

\section{SUGGESTION}

Further research is required to study the histology of the reproductive organs, reproductive behavior and physiology of female bandicoot (E. kalubu) in captivity.

\section{ACKNOWLEDGEMENT}

We acknowledge the assistance of editors and reviewers, in improving the manuscript.

\section{REFERENCES}

Ballantyne K, Matson P, Noakes N, Nicolson V, Johnston SD. 2009. Reproductive Physiology of the Female Greater Bilby (Macrotis lagotis Thylacomidae: Evidence for a MaleInduced Luteal Phase). Journal Reproductive, Fertil and Develop 21: 274-282.

Barbour RA. 1977. Antomy of Marsupial. In The Biology of Marsupials, eds Stonehouse B, Gilmore RT. London: Macmillan. Pp. 237272.

Biscoe RT, Renfree M. 1987. Reproductive Physiology of Marsupials. New York. Cambridge University Press. Pp. 124-171.

Fletcher JJ. 1881. On The Existence after Parturition of Direct Communication between the Median Vaginal Cul-de-sac socalled, and the Urogenital Canal, in Certain Species of Kangaroo. Proceedings of the Linnean Society of New South Wales, 6: 796-811.

Fletcher JJ. 1883. On Some Points in the Anatomy of Urogenital Organs in Females of Certain Species Kangaroos. Part 2. Proceedings of the Linnean Society of New South Wales, 8: 6-11. 
Hafez ESE. 2000. Anatomy of Female Reproduction, in Reproductionin Farm Animals, Hafez ESE. Ed. $7^{\text {th }} \mathrm{ed}$. Philadelphia. Lea \& Febiger.

Murwanto, Junaedi M, Kusrini-Gatot DS. 2008. Tingkat konsumsi daging bandikut oleh penduduk lokal dan faktor-faktor yang mempengaruhinya di Distrik Warmare Kabupaten Manokwari. Ternak Tropika Juni 2008. http://portalgaruda. fti.unissula. ac.id/index.php?ref=browse\&mod= viewarticle\&article $=10415$

Koibur JF, Kustono, Widayati DT. 2011. Karakteristik dan Organ Reproduksi Betina Kanguru Pohon Kelabu (Dendrolagus inustus). Buletin Peternakan 35(1): 17-23.

Larcombe AN. 2003. Activity Rithms of Sourthen Brown Bandicoots Isoodon obesulus (Marsupialia: Peramelidae) in Captivity. Journal Australia Mammal. 25:81-86.

Lister JJ, Feltcher JJ. 1881. On The Condition of the Median Portion of the Vaginal Apparatus in the Macropodidae. Proceedings of the Zoological Society of London, Hlm. 976-96.

Long K. 2009. Burrowing Bandicoots an Adaptation to Life in Fire Prone Environment. Journal Australia Mammal 31: 57-59.

Maker UP, Nisa C, Agungpriyono S. 2015. The Morphology External Organs of The Body of Bandicoot Echymipera kalubu. ICSBP Conference Proceedings International Conference on Social Science and
Biodiversity of Papua and Papua New Guinea. Hlm. 55-61. DOI 10.18502/ kss.v1i1.434.

Pattiselanno F. 2003. The Wild Life Value: Example from West Papua, Indonesia. Tiger Paper30(1): 29-27.

Petocz RG. 1994. Mamalia Darat Irian Jaya. Jakarta. Penerbit Gramedia Pustaka Utama. Hlm. 69-77.

Tethool AN, Arifiantini RI, Agungpriyono S. 2012. Konsentrasi dan Motilitas Spermatozoa Cauda Epididymis Bandikut (Echymipera kalubu). Jurnal Ilmu Peternakan 7(1): 26-30.

Thodunter R, Gemmel RT. 1987. Seasonal Changes in the Reproductive Tract of the Male Marsupials Bandicoot, Issodon macrourus. Great Britain. Journal Anatomy 154: 173-186.

Tyndale-Biscoe CH. 1965. The Female Urogenital System and Reproduction of The Marsupial Lagostropus fasciatus. Australian Journal of Zoology 13: 255-67.

Tyndale-Biscoe CH. 1968. Reproduction and Post-natal Development in The Marsupial Bettongia lesueur (Quoy \& Gaimard). Australian Journal of Zoology 16: 577-602.

Vernes K, Pope LC. 2009. Reproduction in the Northern Brown Bandicoot (Isoodon macrourus) in the Australian Wet Tropics. Journal of Zoology 57:_105-109.

Warsono IU. 2010. Karakteristik dan Daging Bandikut (Echymipera kalubu). Jurnal Ilmu Peternakan 5(1):_28-34. 